\title{
Institucija likovne kritike danas
}

\section{Loinjak, Igor}

Source / Izvornik: Institucije povijesti umjetnosti : zbornik 4. kongresa hrvatskih povjesničara umjetnosti, 2019, 143 - 150

Conference paper / Rad u zborniku

Publication status / Verzija rada: Published version / Objavljena verzija rada (izdavačev PDF)

https://doi.org/10.31664/z4khpu.20

Permanent link / Trajna poveznica: https://urn.nsk.hr/urn:nbn:hr:254:446770

Rights / Prava: Attribution 4.0 International/Imenovanje 4.0 međunarodna

Download date / Datum preuzimanja: 2023-04-26

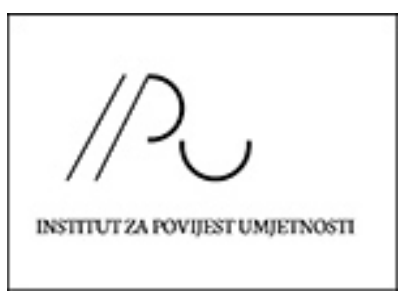

Repository / Repozitorij:

PODEST - Institute of Art History Repository

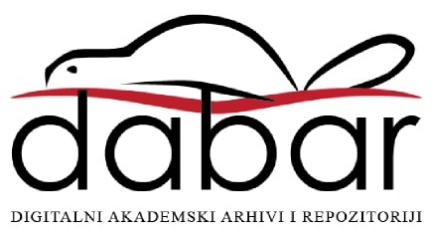




\section{Institucija likovne kritike danas}

\section{Uvod}

Povijesno gledajući, ali i tragajući za teorijskom opravdanošću određenih kritičarskih modela, umjetnička se kritika ne može odrediti kao jednoznačan i jednostavan model analize i valorizacije umjetničkih djela nepodložan povijesnim i kulturološkim promjenama. Mogu se spomenuti dva različita gledanja na umjetničku kritiku koja kritičarskoj djelatnosti nedvojbeno daju više od jednoga mogućeg pristupa. Renato Poggioli pišući o avangardnoj kritici u Teoriji avangardne umjetnosti raspravlja o odnosu klasične i avangardne kritike zaključujući da između njih postoji bitna razlika, koja bi bila vezana uz subjekt kojemu je kritički tekst namijenjen: „Ako se klasični kritičar obraćao, pre svega, umetniku, avangardni kritičar se isuviše često obraća nekolicini kritičara svoje sopstvene sekte, izdajući tako još jednu tradiciju moderne kritike koja, prateći plemenitu tradiciju romantičara i devetnaestog veka, treba da se obraća publici i da osvetljava i umetničko delo i duh koji ga posmatra." Avangardni je kritičar težio razumjeti nove umjetničke pojave više no što ih je nastojao strogo valorizirati. Klasični je pak pristup kritici uglavnom uključivao usporedbu s normativnom poetikom odnoseći se ravnodušno prema „bilo kojoj novini i eksperimentu, poštujući pravilo navike čak više i od kanona vlasti". ${ }^{2}$ Dok Poggioli razlikuje klasičnu i avangardnu kritiku, Grgo Gamulin piše o kritici ex ante i ex post. Prvi je pristup vezan uz avangardizam i odlučujući se za njega kritičar djeluje iz „zamišljenog ili već očitovanog programa” koji „funkcionira u teoretskom smislu i utemeljen je u trenutačno novoj teoriji-programu". ${ }^{3}$ Pristup ex post klasičniji je i nastupa kada djelo kritičar prvi put vidi i doživi. Već sama mogućnost izbora kritičarskoga pristupa ukazuje na element subjektivnosti preliminarno upisan u osobu (subjekt) kritičara, što je osobito potvrdila kritika na djelu osobito šezdesetih i sedamdesetih godina prošloga stoljeća. ${ }^{4}$ Iako prvi kritički zapisi o djelu ne moraju nužno odrediti njegovu sudbinu, oni su nezaobilazna referencija u budućem životu djela, koje će

\section{Igor Loinjak}

Odsjek za vizualne i medijske umjetnosti Akademija za umjetnost i kulturu u Osijeku Sveučilište Josipa Jurja Strossmayera u Osijeku loinjakigor@gmail.com

https://orcid.org/oooo-ooo2-8839-28o8

3 GRGO GAMULIN, Alibi za kritiku, u: Život umjetnosti, 28 (I979.), I6.

4 JASNA GALJER, Kritika na djelu u hrvatskoj umjetnosti 6o-ih i 7o-ih godina 2o. stoljeća, u: Radovi Instituta za povijest umjetnosti, 36 (2ог2.), 2г9-226. 
u budućnosti zadržati ili promijeniti status te možda dobiti kanonsku vrijednost koja je, unatoč stanovitoj subjektivnosti kritičara, u konačnici ozakonjena kao objektivna vrijednost.

\section{Izmedu kritike i povijesti umjetnosti}

U tekstu Medijacijska funkcija umjetničke kritike između povijesti $i$ suvremenosti Nataša Lah, pozivajući se na knjigu Povijest umjetničke kritike Lionella Venturija, donosi citat: „U Francuskoj obično nazivaju kritičarima umjetnosti one što pišu u novinama o aktualnim izložbama, a povjesničarima umjetnosti one što pišu o antičkoj umjetnosti. Razlika koja je na kraju prilično opasna, jer navodi kritičare da ne vode računa o povijesti, a povjesničare da budu bez ikakvog dodira s kritikom." Venturi u citiranom odlomku ukazuje na nedostanosti kritičarskoga i povijesnoumjetničkog pristupa istom predmetu analize ako se strogo odvaja kritika od povijesti i obratno. Kritičar, naime, da bi prije donošenja vrijednosnog suda mogao napraviti adekvatnu analizu umjetničkoga djela, nedvojbeno mora posegnuti za poviješću, kao što i povjesničar umjetnosti najčešće već samim izborom umjetničke građe iz prošlosti u nju implicitno upisuje vlastiti vrijednosni sud uzimajući ulogu kritičara.

Odnosa se kritike i povijesti umjetnosti u Alibiju za kritiku dotiče i Gamulin, pišući da „možda neke bitne razlike, koja se ne bi sastojala u tehnici, aparaturi, težnji prema objektivnosti i sabiranju iskustava, i nema". Ali jedna se i druga djelatnost sadržajno nikako ne poklapaju u svem opsegu. „Ono što izdvaja umjetničku kritiku i stvara njezinu posebnu funkciju”, ističe Gamulin, ,jest prvotnost odnosa. Kritika reagira na novo djelo, prvi put objelodanjeno. Ona, s obzirom na njega, nema drugih, tuđih iskustava, i nije, dakle, ni dužna da o njima vodi računa [...]. Njena je uloga velika, premda ne mora biti odlučna ili sudbonosna. Prva kritika nema, u načelu i za to djelo, konkretnih uporišta. Pa ipak, kritičar ima uporišta u svom dotadašnjem (općem i profesionalnom) iskustvu, u svom prethodnom doživljavanju i u doživljavanju ostalih, koje je 'osviješteno', i prešlo u intelektualno iskustvo, u znanje." ${ }^{6}$ Iz Gamulinova je navoda jasno da kritičar uz senzibiliranost treba posjedovati dovoljno znanja kako bi novo djelo provukao kroz brojne profesionalne i stručne skenere, povukao kontekstualne paralele s trenutnim umjetničkim tendencijama, kontekstualizirao ga unutar umjetnikova dotadašnjeg opusa i konačno ukazao na njegove individualne (ne)specifičnosti. Umjetničko djelo redovito nije obeskorijenjeno ni u potpunosti singularno, nego proizlazi iz određene tradicije, pa je kritičaru analiza koja je usmjerena na djelo po sebi, kao i ona koja promatra djelo u kontekstu, temelj svake moguće valorizacije. Zauzimajući stav prema novom i netom viđenu djelu, „kritičar ima parametre položene u nekoliko slojeva vlastitog iskustva, u već viđenom i doživljenom, u svom znanju i sjećanju, u sjećanju ostalih; to mu, u svojoj cjelini, i omogućava kriterij ili intuiciju kojom trenutačno reagira i ocjenjuje." ${ }^{7}$ Hoće li budućnost valorizaciju potvrditi ili
LAH, Medijacijska funkcija umjetničke kritike između povijesti i suvremenosti, u: Ars Adriatica, 2 (20I2.), 272.

6 GRGO GAMULIN (bilj. 3), I9, bilj. 7 .

7 ISTO, 20. 
opovrgnuti u tom je slučaju manje važno. Talijanski se teoretičar suvremene umjetnosti Germano Celant zalagao pak za kritičarski pristup koji bi bio lišen interpretativnoga i valorizacijskog upletanja u djela suvremene umjetnosti, čineći kritičara isključivo motriteljem, dokumentaristom i naposljetku arhivistom $-\mathrm{u}$ etimološkom smislu riječi istinskim kustosom. Intervencija je kritičara suvišna, donosi Celant, jer „teorija i kritika umjetnosti nemaju više potrebe za prosuđivanjem ili tumačenjem, očitovanjem ili podržavanjem jednog fenomena, umjetnosti, koji ne traži više razjašnjenja niti opravdanja, već samo senzorno i mentalno sudjelovanje. Suvremena umjetnost u ovom trenutku zahtijeva da bude ostavljena na miru [...] odbacuje interpretativna uplitanja". ${ }^{8}$

Kritičaru je, dakle, znanje iz povijesti umjetnosti dio profesionalnoga instrumentarija, kao što je povjesničaru umjetnosti sposobnost detaljne analize i prosudbe neizostavan alat među radnim kvalitetama, jer unatoč činjenici da se bavi djelima koje je struka već historizirala, on mora biti u mogućnosti historizirana umjetnička djela približiti publici i specifičnostima konteksta vremena u kojem djeluje, budući da energija umjetničkoga rada biva na različite načine manifestirana $u$ različitim povijesno-društvenim okolnostima.

\section{Vrijednost i Ljepota kao univerzalna svojstva umjetničkoga djela?}

Ako se pretpostavi da je kritičar nalik antičkome Hermesu te posreduje između umjetničkoga djela i publike, njegove bi stručne predispozicije trebale bi razrađenije i istančanije nego što su one prosječnoga recipijenta. Nije nemoguće da se dojam o umjetničkom djelu razlikuje u većega broja pojedinaca. Pišući o nekim problemima recepcije književnoga djela, Zdenko Škreb u djelu Književnost i povijesni suijet priznaje kako se čitatelju ne smije uzeti pravo na njegov osobni stav prema djelu koje sam odabere te da prema istom djelu ne moraju svi čitatelji ostvariti identičan odnos. ${ }^{9}$ Znanost o književnosti, međutim, ne može tako olako preći preko pitanja vrednovanja jer je ono često nerazdjeljivo od oblikovanja korpusa najkvalitetnijih djela. Isto se može reći i za povijesnoumjetničko područje. Leonid Stolovič proces vrednovanja poistovjećuje sa začaranim krugom-vrijednost je s jedne strane kriterij vrednovanja, dok je istodobno ona dostupna samo putem vrednovanja. ${ }^{10}$ Roman Ingarden stvari postavlja nešto drukčije, razlikujući sud vrijednosti i estetsko vrednovanje. Prvi ne ovisi o estetskom doživljaju i može biti donesen kao intelektualni čin, posve naslijepo. Pritom je problem, priznaje Ingarden, $\mathrm{u}$ tome što je tako iznesen sud lišen odgovarajućeg utemeljenja. ${ }^{11}$ Različite umjetničke teorije ne stavljaju naglasak na iste umjetničke aspekte djela pa, prema tome, vrednovanje djela nije uvijek usuglašeno. ${ }^{12}$

Povijest se estetike može odrediti i kao povijest promišljanja o ideji (i objektivnosti) Ljepote. Veliki je preokret nastupio s Immanuelom Kantom, koji pojam lijepo premješta iz polja
8 GERMANO CELANT, Za akritičnu kritiku, u: Novine Galerije Studentskog centra, 24 (I970.), 88.

9 ZDENKO ŠKREB, Književnost i povijesni svijet,Zagreb, I98I., 8.

Io LEONID STOLOvič, Suština estetske vrednosti, Beograd, I983. [I972.], I92.

II ROMAN INGARDEN, Doživljaj, umetničko delo i vrednost, Beograd, I975. [1969.], I8.

I2 Na taj je problem ukazao već Benedetto Croce kada je u članku Kritika i umjetnost napisao kako se često događa da zbog različitog definiranja umjetnosti [a isto tako i različite teorijske ili poetike orijentacije pojedinih književnih kritičara] dvije osobe potpuno drukčije tumače vrijednost nekog djela. BENEDETTO CROCE, Brevijar estetike, Zagreb, 2003. [I9I2.], IO5. 
objektivnoga u polje subjektivnog: „Sud ukusa nije dakle sud spoznaje, dakle ne logički, nego estetički, pod kojim se ne razumijeva onaj sud, čiji odredbeni razlog može da bude samo subjektivan." ${ }^{13}$ Estetički je sud bezinteresan (za razliku od spoznajnog ili moralnog suda) te za ukus ne može postojati objektivna norma: „Ne može biti objektivnoga pravila ukusa, koje bi s pomoću pojmova određivalo, što je lijepo. Jer svaki je sud iz toga izvora estetički, t. j. njegov je odredbeni razlog subjektov osjećaj, a ne pojam nekoga objekta. Tražiti princip ukusa, koji bi opći kriterij lijepoga naveo s pomoću određenih pojmova, jest jalov trud, jer je ono, što se traži, nemoguće i samo po sebi protivurječno." ${ }^{14}$ Kantu je ipak bilo važno sačuvati estetski sud od relativizma pred kojim se našao pa ističe: „U pogledu ugodnog vrijedi dakle načelo: suatko ima svoj vlastiti ukus (osjetila). S lijepim stoji posve drukčije. Bilo bi (upravo obratno) smiješno, kad bi se netko, tko bi sebi uobražavao nešto na svoj ukus, mislio opravdati ovim: ovaj predmet [...] jest za mene lijep. [...] ako za nešto kaže, da je lijepo, onda on to isto sviđanje očekuje i od drugih; on ne sudi samo za sebe nego za svakoga i govori onda o ljepoti, kao da je ona svojstvo stvari." ${ }^{15}$ Kant se zalaže za estetski sensus communis na koji se obrušio Gérard Genette $u$ svom Estetskom odnosu. Genette je, oslanjajući se na Kantove izvode, zaključio kako iz subjektivne prirode estetskoga suda proizlazi nemogućnost racionalnog utemeljenja vrijednosti, pa sensus communis ni na koji način ne može biti univerzalan i aprioran. Proučavanje umjetničke vrijednosti stoga nema nikakav opravdan ni prihvatljiv kriterij. ${ }^{16}$

\section{Suodnos ukusa i vrijednosti}

Problemom ukusa, osobito onog lošeg, opsežno se pozabavio Milivoj Solar u studiji Predavanja o lošem ukusu. Polazeći od Kantove definicije ukusa, Solar omeđuje pojam lošeg ukusa određujući ga kao pomanjkanje moći estetičkog prosuđivanja. ${ }^{17}$ On odbacuje bilo kakvu mogućnost postojanja subjektivnog ukusa: „Pri tome vas moram, nažalost, upozoriti da je osobni ukus fikcija: ako jedino ja mislim da je pjesma mojeg prijatelja vrhunsko dostignuće pjesništva, jer je prema mojem osobnom ukusu, to ne može značiti ništa; ukus mora pripadati nekoj zajednici, i tek ako postoji neka zajednica onih koji se slažu u procjenjivanju može se govoriti o dobrom i lošem ukusu."18 Upravo je ukus zajednice kantovski sensus communis. Tko sačinjava tu zajednicu? Prosječni recipijenti, stručna javnost sastavljena od kritičara, kustosa i umjetnika ili svi oni skupa? Solar je već i ranije, pozivajući se na Welleka i Warrena, odbacivao mogućnost osobnog vrednovanja djela: „Ako je umjetnički doživljaj uvijek moj osobni, subjektivni doživljaj, pa je i književna vrijednost uvijek samo moja osobna, subjektivna i individualna vrijednost, svatko ima, strogo uzevši, vlastitu Božanstvenu komediju, svojega Hamleta i svojega Uliksa. Takva tvrdnja doduše može goditi taštini modernih čitalaca, ali je čak i Wellek i Warren, kojima inače nije sasvim strana ideja o umjetničkom doživljaju, u svojoj Teoriji knjižeunosti s pravom
I3 IMMANUEL KANT, Kritika rasudne snage, Zagreb, I957. [I790.], 4I.

I4 ISTO, 70 .

I5 ISTO, 50-5I.

i6 ANTOINE COMPAGNON, Demon teorije, Zagreb, 2007. [I998.], 27I.

I7 MILIVOJ SOLAR, Predavanja o lošem ukusu: obrana estetičkoga uma, Zagreb, 2004., II.

I8 ISTO, 20. 
osuđuju." ${ }^{19}$ Autor je svjestan problema pred kojim se nalazi tako da poglavlje u kojem se bavi tom problematikom naslovljava Antinomije knjižeunih vrijednosti. ${ }^{20}$ Premda Solar odbacuje osobni ukus kao relevantan obrazac za vrednovanje djela, ne odbacuje mogućnost, o kojoj je pisao Škreb, da različiti čitatelji ne moraju prema nekom djelu zauzeti identičan stav. Ali ono što Solar traži od recipijenta koji izriče vrijednosni sud nije samo izjava „to mi se (ne) sviđa”, nego je tu izjavu potrebno obrazložiti tako što će se na određeni način ući u opis predmeta, a susljedno s time i u stanovito tumačenje i valorizaciju. ${ }^{21}$

Problem se ukusa našao i u sferi interesa spomenutoga ruskog estetičara Leonida Stoloviča. Stolovič estetski ukus vidi kao subjektivni kriterij vrednovanja, ${ }^{22}$ što se djelomično razlikuje od Solarova shvaćanja. Međutim, Stolovič je svjestan poteškoća pred kojima se našao te priznaje kako je vrednovanje prema ukusu intuitivno i nema čvrsta objektivnog utemeljenja. Pouzdaje se stoga u sposobnost razvijanja ukusa jer on nikom nije a priori dan, nego ga je potrebno oblikovati sumiranjem ranijeg estetskog iskustva: „Estetski ukus se formira pod uticajem određenih okolnosti, u zavisnosti od društvene sredine u kojoj protiče naš život i rad, u zavisnosti od umetničkih dela koja mi opažamo." ${ }^{3}$ Tako shvaćen, ukus, premda subjektivan, ipak ostaje u području kolektivnoga iskustva te dobiva stanovite naznake objektivnosti. Ipak, i dalje ostaje činjenica (i mogućnost) da likovni kritičari različitih senzibiliteta različito vrednuju isto umjetničko djelo ili opus služeći se argumentima koji proizlaze iz različitih teorijskih stavova i mogućnosti (koji prema tome uvjetuju i različite kriterije pr/ocjene), ostavljajući pod znakom upitnika objektivnu vrijednost djela. Odnosno, opravdano je pitanje postoji li doista objektivna vrijednost upisana u umjetnički predmet te objektivni kriteriji prema kojima se kritičari mogu ravnati? Gamulin je skeptičan: „I sama je vrijednost (vrijednost $z a$ čovjeka) odnos; ona, naime, ne može biti ni u predmetu ni u subjektu, nego u njihovoj (povijesno promjenljivoj) relaciji. Ima li, međutim, umjetnički predmet (ili fenomen) vrijednost po sebi i za sebe? Možda bi uopće trebalo zaobići taj problem, nerješiv kao što je nerješiv i problem svijeta za sebe." 24

\section{Kanon(izacija)-ozakonjenje vrijednosti}

Francuski sociolog umjetnosti Pierre Bourdieu zastupa tezu o paradoksalnoj promjeni u recepciji, odnosno o obrnuto proporcionalnom odnosu prvotne popularnosti i kasnije kanoničnosti književnog, ali i svakog umjetničkog djela. ${ }^{25}$ Opravdanje toga, prema Bourdieuovu mišljenju, leži u činjenici što djela kvalitetnih umjetnika u početku zanimaju isključivo druge kvalitetne umjetnike i time oblikuju smjernice za otkrivanje novih, dotad još stranih područja umjetničkoga stvaralaštva. Sličnu je tezu ponudila i estetika recepcije. Hans Robert Jauß dobar kriterij za određivanje vrijednosti djela vidi u njegovoj prvotnoj recepciji, u kojoj mjeri ono ispunjava, nadilazi ili opovrgava očekivanja prve publike-tzv. estetski otklon. Vrhunska
I9 MILIVOJ SOLAR, Književna kritika i filozofija književnosti, Zagreb, I976., I43.

20 ISTO, I39-I47.

2I MILIVOJ SOLAR (bilj. I7), 3 o.

22 „I estetski ukus ne postoji van ličnosti i ne može a da ne bude lična pojava.” LEONID STOLOVIČ (bilj. Io), 200.

23 ISTO, I98-I99.

24 GRGO GAMULIN (bilj. 3), I4.

25 Bourdieu se tim pitanjem opširno bavi u poglavlju Le marché des biens symboliques svog kapitalnog djela Les règles de l'art. Genèse et structure du champ littéraire (I. izdanje I992.). Usp. engleski prijevod: PIERRE BOURDIEU, The Rules of Art. Genesis and Structure of the Literary Field, Stanford, I995., I4I - I73 (poglavlje The Market for Symbolic Goods). 
su umjetnička ostvarenja ona, tvrdi Jauß, kod kojih postoji veći raspon između djela i očekivanja prve publike, premda se za buduće generacije on redovito smanjuje. Istoj kategoriji pripadaju i djela koja nemaju prvu publiku, već ju je tek potrebno oblikovati. ${ }^{26}$

S kvalitetnim su umjetnicima povezana vrhunska i vrijedna, kanonska umjetnička djela. Hans Georg Gadamer je u 2o. stoljeću pokušao obnoviti pojam klasičnog, povezan i s kanon(izacij)om, sa svrhom oslabljivanja Kantova i Humeova relativizma. Prema Gadamerovu je mišljenju klasično djelo ono koje skriva pukotinu nezamjetljivu suvremenicima, zahvaljujući kojoj preživljava u budućnosti: „[...] klasično je ono što izdržava [povijesnu] kritiku, jer njegova povijesna vladavina, obvezujuća moć njegova baštinjenog i očuvanog [autoriteta], prethodi svoj [povijesnoj] refleksiji i u njoj se odražava."27 Spomenuto je da svako (značajno) djelo stoji u određenom tradicijskom odnosu prema prošlosti i budućnosti pa je predmet interesa kako kritičaru tako i povjesničaru umjetnosti. Gaëtan Picon prilikom raspravljanja o kanonizaciji djela napose uzima u obzir budućnost djela, napominjući da njegova važnost ne ovisi samo o prijašnjim djelima i trenutku nastanka nego i o djelima koja će doći. Za potkrepljenje te tvrdnje poslužio mu je primjer iz područja likovnih umjetnosti-El Greca, piše Picon, najavljuje Tintoretto, ali njegova se važnost zaokružuje tek u djelima Paula Cézannea. ${ }^{28}$

Većini je stručnjaka za umjetnost teško prihvatiti sve rašireniju tezu o relativnosti umjetničke vrijednosti. Bilo je pokušaja očuvanja objektivnosti suda ukusa na kojem bi se temeljilo i objektivno vrednovanje djela, a time i oblikovanje kanona, premda oni nisu postali trajnom svojinom struke. Čini se da je Kant sasvim nenamjerno otvorio Pandorinu kutiju. Rješenje se pokušalo naći u radovima analitičkih estetičara koji su se barem djelomično pokušali vratiti objektivizaciji umjetničkih vrijednosti. Jedan je od rodonačelnika na tom području Monroe Beardsley. On je u djelu Aesthetics: Problems in the Philosophy of Criticism između objektivnosti i relativizma ponudio srednji put-instrumentalističku teoriju. Prema predloženom shvaćanju, „estetska vrijednost ovisi o rasponu doživljaja što ga pobuđuje estetski predmet, ili točnije, o rasponu estetskog doživljaja koji je kadar pobuditi, sa stajališta triju glavnih kriterija, a to su jedinstvenost, složenost i snaga potencijalnoga doživljaja." ${ }^{29}$ Beardsley je smatrao da je s pomoću ta tri kriterija moguće objektivno vrednovanje umjetničkoga djela, to jest da s pomoću njih svaki recipijent argumentirano može zaključiti da je neko djelo vrednije od nekog drugog. Beardsley inzistira na istoj stvari kao i Solar-nije dovoljno reći sviđa li mi se neko djelo ili ne, već je vlastiti stav potrebno argumentirano obrazložiti. ${ }^{30}$ No, i kod Beardsleyja ostaje problem utemeljenja tih triju modela. Čak i ako se prihvati da jedinstvenost i složenost ulaze u područje objektivnoga, pitanje snage i dalje ostaje rezervirano za svakoga pojedinačno. Genette je Beardsleyjevu teoriju smatrao nedosljednom, a u njegovim je terminima jedinstvenosti, složenosti i snage iščitavao koncepte integritas, consonantia i claritas Tome Akvinskog. ${ }^{31}$
26 HANS ROBERT JAUS [JAUIS], Estetika recepcije. Izbor studija, Beograd, ı978., 64-66 (Istorija knjižeunosti kao izazou nauci o knjižeunosti, I967.).

27 ANTOINE COMPAGNON (bilj. I6), 262-283.

28 GAETAN PIKON [GAËTAN PICON], Uvod u jednu estetiku književnosti. Pisac i njegova senka, Beograd, I965. [I953.], 78.

29 ANTOINE COMPAGNON (bilj. I6), 288. Compagnon ovdje parafrazira Beardsleyjev tekst: MONROE BEARDSLEY, Aesthetics: Problems in the Philosophy of Criticism, Indianapolis, I98I. [I958.], 529.

30 MILIVOJ SOLAR (bilj. I7), 30 .

3I ANTOINE COMPAGNON (bilj. I6), 289. O tome Genette piše u: GÉRARD GENETTE, La Relation esthétique, Paris, I997., 94. 
U jednom se trenutku koncept vremena nametnuo kao jako dobar saveznik u sukobu između objektivnosti i relativnosti umjetničke vrijednosti. Polazilo se, naime, od činjenice da će vrijeme dati konačnu presudu o pitanju kvalitete nekog djela, koja ne mora biti u skladu s kritičkim sudom donesenim u trenutku prvoga kritičarskog odnosa prema djelu. Ako ono uistinu vrijedi, vrijednost se za recipijente neće mijenjati u vremenu, a ukoliko podlegne protoku vremena, utoliko se teško može prihvatiti teza suvremenika o njegovoj izvanrednoj kvaliteti. Problem je što komponenta vremena, tj. buduća recepcija umjetničkoga djela, za kritičara ne postoji jer je njegova pozicija djelovanja određena hic et nunc.

Doduše, ni za povjesničara umjetnosti ona ne mora biti sveto pravilo jer ni komponenta vremena nije posve siguran parametar određivanja univerzalne umjetničke vrijednosti. Povjesničar umjetnosti Francis Haskell analizirajući povijest ukusa došao je do zaključka da vladajući ukus u velikoj mjeri utječe na trenutnu vrijednost određenog djela. Budući da je ukus sklon mijenama, nitko ne može biti posve siguran da umjetnik koji je nakon određenog vremena stekao visok status neće $\mathrm{s}$ vremenom opet pasti u zaborav. ${ }^{32} \mathrm{U}$ skladu s brojnim pristupima iznesenima u prethodnome tekstu, može se ponuditi mišljenje Compagnona, koji vlastiti stav o pitanju kritike obrazlaže ovako: „Naravno, nije moguće bjelodano pokazati da su estetske hijerarhije racionalne, ali to ne priječi da se racionalno proučava kretanje vrijednosti, kao što čine povijest ukusa ili estetika recepcije. Nemogućnost da racionalno obrazložimo zašto nečemu dajemo prednost, kao i da analiziramo ono po čemu začas prepoznajemo lice ili stil-Individuum est ineffabile-ne isključuje mogućnost da empirijski utvrdimo konsenzuse koji su ishod kulture, mode ili čega drugog. [...] Književna [općenito umjetnička, op. a.] se vrijednost ne može utemeljiti teorijski: ona je granica teorije, a ne književnosti [ili neke druge umjetnosti, op. a.]." ${ }^{33}$ Ipak, na području kritike koja se bavi djelima koja tek ulaze u svijet umjetnosti nije moguće proučavati vremensko kretanje vrijednosti jer će ono biti moguće tek u budućnosti kada se njime budu eksplicitnije bavili povjesničari umjetnosti, kojima će biti nedvojbeno jednostavnije objektivno ih kanonizirati ili ne. Preostaje stoga zaključiti da je objektivnost likovne kritike uvelike podložna subjektu-kritičaru koji djelo valorizira. Zato je moguće dobiti različite valorizacijske osvrte na ista umjetnička djela, što je osobito čest slučaj u novijim razdobljima, kada produkcijska raznolikost širi lepezu umjetničkih mogućnosti do granica koje kritičarima nije moguće objektivno zaokružiti, no zasigurno će povjesničarima umjetnosti u budućnosti biti lakše to učiniti. Kritičarima, pak, ostaje pouzdanje u vlastito znanje te parafraza stava Johanna Gottlieba Fichtea, koji piše: „Kakva se filozofija [umjetnost] odabire [zastupa], zavisi od toga, kakav je tko čovjek, jer filozofski sistem [generalno shvaćanje umjetnosti oblikovano određenim teorijskim obrascem] nije mrtav komad pokućstva, koji se može odložiti ili prihvatiti, kako nam je po volji, nego je oduhovljen dušom [te brojnim svjetonazorskim faktorima i stečenim znanjem] čovjekovom, koji ga ima."34
32 ISTO, 294. Izvorno u: FRANCIS HASKELL, Rediscoveries in Art: Some Aspects of Taste, Fashion and Collecting in England and France, Oxford, 1976. 33 ANTOINE COMPAGNON (bilj. I6), 296.

34 JOHANN GOTTLIEB FICHTE, Odabrane filozofske rasprave, Zagreb, I956., I86 (Prvi uvod u nauku o znanosti, I797.). Uglate zagrade znače op. $a$. 


\section{Zaključak}

Kratka tematizacija problema likovne kritike u suvremenosti te (ne)mogućnosti njezine objektivnosti iznesena u prethodnom tekstu pokazala je da dugotrajan sukob između zastupnika objektivne i subjektive (relativističke) kritike još nije nadiđen. Neka teorijska rješenja predložena u obliku različitih pristupa likovnoj i općenito umjetničkoj kritici ne mogu se smatrati univerzalnim obrascem kojemu se opravdanost ne može dovesti u pitanje. Štoviše, kritičarska praksa pokazuje da valorizacijski sukobi i dalje ostaju legitimni modeli kojima kritičari novonastala umjetnička djela uvode u svijet umjetnosti pripisujući im ili otpisujući vrijednost, premda prvotna recepcija čak i kada je ozakonjena tekstom relevantnoga kritičara ne mora nužno određivati sposobnost umjetničkoga djela za dalje snalaženje u svijetu u kojem počinje participirati. Mogućnost oprečnih pristupa valorizaciji umjetničkoga djela ne govori isključivo o relativnosti (objektivnih) kriterija, već ozakonjuje kretanje kritičarskoga fokusa po većem broju estetskih punktova po modelu subjektivnoga odabira, odnosno osobnog nahođenja uvjetovana brojnim izvanjskim faktorima. Konačno, svaki je kritički zapis samo jedno moguće suočavanje s novonastalim umjetničkim djelom te ponekad više govori o kritičaru nego o djelu samu. Otvorenost stoga kritičke analize ne ide isključivo u prilog relativizmu kriterija vrednovanja, nego potvrđuje otvorenost ljudskoga duha prema umjetničkome djelu, koje je u konačnici iz duha i nastalo.

\section{(ㅇ) (i)}

Institucija likovne kritike danas / Igor Loinjak/ CC BY / 4.0

DoI: https://doi.org/Io.3I664/z4khpu.2o 